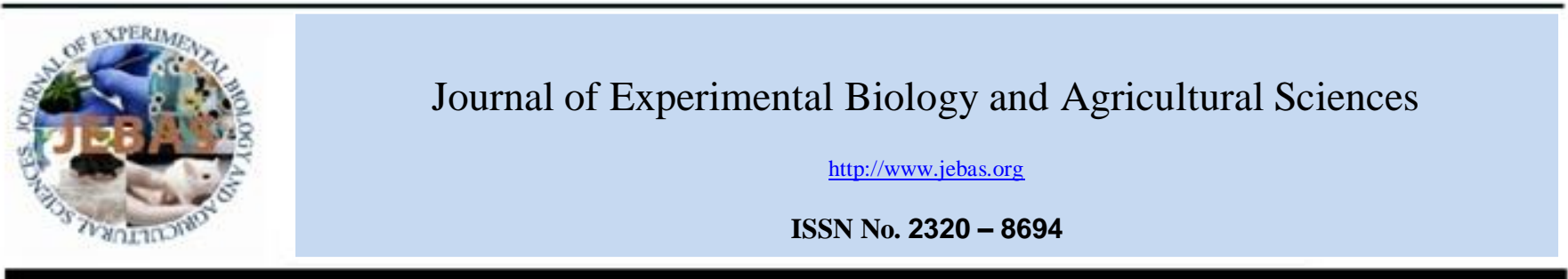

\title{
COMBINING ABILITY FOR GRAIN YIELD AND ITS COMPONENT TRAITS IN MAIZE (Zea mays L.)
}

\section{P. Roopa Sowjanya*, E. Gangappa, S. Ramesh}

Department of Genetics and Plant Breeding, University of Agricultural Sciences, GKVK, Bengaluru - 560065

Received - June 01, 2019; Revision - July 14, 2019; Accepted - July 25, 2019

Available Online - August 05, 2019

DOI: http://dx.doi.org/10.18006/2019.7(4).376.381

\section{KEYWORDS}

Anthesis-Silking Interval

Inbreds

Single cross hybrids

General combining ability

Per se performance

\begin{abstract}
Testing of inbred lines for general combining ability $(g c a)$ enables plant breeders to discard undesirable ones and identify those that are desirable for the production of superior hybrids. In this context, 16 inbred lines were selected on the basis of grain yield and were evaluated for their gca related to grain yield plant ${ }^{-1}$ and its attributing traits. The analysis of variance revealed significant differences among the inbred lines for their per se performance as well as their gca. Similarly the hybrids differed significantly for per se performance and their specific combining ability ( $S C A)$ effects for all the traits. Five of the 16 inbred lines were identified as good general combiners for grain yield plant $^{-1}$. Non-significant correlation between per se performance and gca effects suggested that per se performance of inbred lines is not a good indicator of their gca effects for any of the traits. However, significant positive and fairly high magnitude of correlation between per se performance of hybrids and sum of parental gca effects indicated good predictability of hybrids per se performance based on their parental gca effects for all the traits investigated.
\end{abstract}

* Corresponding author

E-mail: 2010rupasowjanya@gmail.com (P. RoopaSowjanya)

Peer review under responsibility of Journal of Experimental Biology and Agricultural Sciences.

Production and Hosting by Horizon Publisher India [HPI] (http://www.horizonpublisherindia.in/).

All rights reserved.
All the articles published by Journal of Experimental Biology and Agricultural Sciences are licensed under a Creative Commons Attribution-NonCommercial 4.0 International License Based on a work at www.jebas.org.

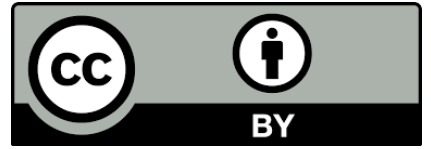




\section{Introduction}

Single cross hybrids are the major cultivar types used for commercial production of maize in most parts of the world. Hybrids have played a vital role in increasing the area and productivity of maize. Superior hybrids are produced if the parents involved have good general combining ability ( $g c a$ ), which is the relative ability of a genotype to transmit its genes with additive effects to its progeny. The concept of gca (Sprague \&Tatum, 1942) is a widely accepted criteria for assessing the inbreds for their use as parents in the development of heterotic hybrids.

Testing of inbreds for their gca effects enables plant breeders to discard most of the undesirable inbreds and allows greater expenditure of resources on most promising ones and identifies those that are desirable for the production of superior hybrids (Bernardo, 2010; Ali et al., 2011; Ai-Zhi \& Zheng, 2012; Fasahat et al., 2016; Hosana et al., 2016 ). Apart from providing an objective criterion for choosing parents, gca also provides useful clues about mode of action of genes controlling economically important traits. Another utility of gca of the parents is their predictive power of hybrid per se performance in the absence of significant hybrid specific combining ability (sca) effects. Under these premises, an investigation was undertaken to assess the gca of inbred lines and hybrids of maize

\section{Materials and Methods}

\subsection{Basic material}

Based on prior evaluation of 16 inbred lines of maize were selected based on high grain yield, and they constituted the basic genetic material.

\subsection{Development and field evaluation of experimental material}

These 16 inbreds were crossed following half diallel mating design (Hayman, 1954) to develop 120 single cross hybrids (SCH) during summer 2015 at the experimental plots of the Department of Genetics and Plant Breeding (GPB), University of Agricultural Sciences (UAS), Gandhi Krishi Vignana Kendra (GKVK), Bengaluru. The resultant $120 \mathrm{SCH}$, their parents and two checks viz., Hema and Nithyashree constituted the experimental material and were evaluated following simple lattice design. Each entry was sown in two-rows of 3 $\mathrm{m}$ length with a spacing of $0.6 \mathrm{~m} \times 0.3 \mathrm{~m}$. All the recommended package of practices was followed to raise a healthy crop.

\subsection{Sampling of plants and data collection}

Data were recorded on five randomly selected plants in both the replications, on each hybrid, parent and checks for grain yield plant ${ }^{-1}$ and its attributing traits.

\subsection{Statistical analysis}

Replication wise mean data of hybrids, parents and checks was used for statistical analysis. Data of $F_{1}$ hybrids were subjected to combining ability analysis following diallel model (Hayman, 1954; Griffing, 1956). The $g c a$ effects of 16 lines were estimated and their statistical significance was examined using ' $t$ 'test.

\subsection{Relationship of gca effects of inbred lines with their per se performance}

Relationship between per se performance of 16 inbred lines and their gca effects were determined by estimating Spearman's Rank Correlation Coefficient for all the traits. Higher magnitude of positive significant and non-significant correlation indicates good and poor predictive power of per se performance, respectively.

\subsection{Relationship of hybrid per se performance with sum of parental gca effects}

Pearson's Correlation Coefficients between hybrids per se performance and sum of gca effects of their parents were estimated for all traits (Schrag et al., 2009). Significant correlation with fairly high coefficients of correlation and determination was interpreted as high predictability of hybrid per se performance based on their sum of parental gca effects.

\section{Results and Discussion}

\subsection{Analysis of variance (ANOVA)}

ANOVA indicated significant differences among single cross hybrids for all the traits (Table 1). Significant mean squares due to inbreds and hybrids suggested substantial variability for $g c a$ effects of inbreds and sca effects of their crosses for all the traits. Significant variances among the crosses could be attributed to greater diversity between inbreds for the traits considered. The mean squares attributable to inbreds and crosses for all the traits indicated greater contribution of the inbreds towards total variation among the hybrids (Kanagarasu et al., 2010).

\subsection{General combining ability of inbred lines}

The practical phase of hybrid maize breeding is identification of elite inbred lines with high $g c a$ for use as parents for developing hybrids that are superior to existing ones (El-Hosary, 2014). Identification of such elite inbred lines is the major strategy adopted by most commercial plant breeders to maximize genetic gain per unit time and resources. This assumption is based on the reports that gca is controlled by additive effect genes which control the inheritance of phenotypes that are fixable (Ai-Zhi \& Zheng, 2012).

In the present study, the inbred lines differed widely for their gca effects for all the Six quantitative traits. The differences in $g c a$ effects of the inbreds are attributable to differences in frequencies of genes that are transmitted to the progeny with the additive effects (Falconer \& Mackay, 1996). The differences in gene frequencies among the inbreds suggest their significant genotypic differences, thus justifying their selection for the present study. 
Different inbred lines were desirable general combiners in both direction and magnitude for different traits (Table 2). Thus, no single line was a desirable combiner for all the seven traits. For instance, inbreds such as MQPM 43, 18816, MAI 386, 18701 and 754 were desirable general combiners for only grain yield plant ${ }^{-1}$, plant height, number of kernel rows ${ }^{-1}$, ear length and ASI, respectively (Table 2). However, inbred lines MAI 386 and MQPM 43 were good general combiners for four traits, namely ASI, ear length, Kernel row ${ }^{-1}$ and grain yield plant ${ }^{-1}$. Thus the inbred lines MAI 315, MAI 157 and M2 need greater attention and need to be evaluated on a large scale to confirm their superiority for gca effects. It should however be noted that the estimates of $g c a$ effects of 16 inbred lines are relative to and are dependent on particular set of parents included in the experiment (Fasahat et al., 2016).

Table 1 ANOVA of $16 \times 16$ half diallel crosses and their parents for grain yield and its component traits in maize

\begin{tabular}{|c|c|c|c|c|c|c|c|}
\hline Sources of variation & $\begin{array}{l}\text { Degrees of } \\
\text { freedom }\end{array}$ & $\begin{array}{l}\text { Anthesis Silking } \\
\text { Interval (days) }\end{array}$ & $\begin{array}{l}\text { Ear length } \\
(\mathrm{cm})\end{array}$ & $\begin{array}{l}\text { Ear width } \\
(\mathrm{cm})\end{array}$ & $\begin{array}{c}\text { Kernels } \\
\text { rows ear }{ }^{-1}\end{array}$ & $\underset{-1}{\text { Kernels row }}$ & $\begin{array}{c}\text { Grain yield } \\
\text { plant }^{-1}(\mathrm{~g})\end{array}$ \\
\hline Replications & 1 & 2.88 & 1.26 & 0.56 & 0.05 & 1.13 & 2152.69 \\
\hline Inbreds + Hybrids & 135 & $1.371 * *$ & $9.75^{* *}$ & $2.03 * *$ & $32.87 * *$ & $3.70 * *$ & $2048.80 * *$ \\
\hline Inbreds & 15 & 0.36 & $8.02 *$ & $2.58 * *$ & $47.34 * *$ & $5.13^{* *}$ & $1895.80 * *$ \\
\hline Hybrids & 119 & $1.48 * *$ & $9.85^{* *}$ & $1.95^{* *}$ & $30.48 * *$ & $3.37 * *$ & $2080.05 * *$ \\
\hline Indreds Vs. Hybrids & 1 & 2.89 & $23.56 *$ & $3.75 *$ & $100.14^{*}$ & $20.84 * *$ & 625.38 \\
\hline Error & 135 & 0.75 & 4.47 & 0.70 & 15.47 & 1.12 & 847.77 \\
\hline Total & 271 & 1.07 & 7.09 & 1.37 & 24.09 & 2.41 & 1450.89 \\
\hline GCA & 15 & $1.22^{* *}$ & $9.86^{* *}$ & $1.39 * *$ & $24.36 * *$ & $3.00 * *$ & $1867.03 * *$ \\
\hline SCA & 120 & $0.61 * *$ & $4.25 * *$ & $0.97 * *$ & $15.44 * *$ & $1.70 * *$ & $919.07 * *$ \\
\hline Error & 135 & 0.37 & 2.23 & 0.35 & 7.74 & 0.56 & 423.88 \\
\hline
\end{tabular}

Table 2 Estimates of general combining ability of 16 inbreds for grain yield and its component traits in maize

\begin{tabular}{|c|c|c|c|c|c|c|}
\hline Inbreds & $\begin{array}{c}\text { Anthesis Silking } \\
\text { Interval (days) }\end{array}$ & $\begin{array}{l}\text { Ear length } \\
\quad(\mathrm{cm})\end{array}$ & Ear width $(\mathrm{cm})$ & Kernels rows ear ${ }^{-1}$ & Kernels row $^{-1}$ & $\begin{array}{c}\text { Grain yield plant } \\
{ }_{(\mathrm{g})}\end{array}$ \\
\hline MAI 137 & $0.43 * *$ & $-1.46^{* *}$ & $-0.40 * *$ & $-1.35^{*}$ & $-0.42 *$ & $-14.51 * *$ \\
\hline MAI 157 & $-0.38 * *$ & $-1.03 * *$ & 0.04 & -0.75 & -0.19 & 5.60 \\
\hline MAI 315 & $-0.34 *$ & 0.12 & 0.17 & 0.96 & $-0.72 * * *$ & $12.17^{*}$ \\
\hline MAI 327 & 0.07 & -0.06 & 0.01 & -0.68 & 0.18 & 1.72 \\
\hline MAI 360 & $0.31 *$ & -0.13 & 0.08 & -0.10 & 0.24 & 5.12 \\
\hline 754 & $-0.41 * *$ & -0.52 & $-0.51 * *$ & -1.00 & -0.31 & $-13.63 * *$ \\
\hline 18758 & -0.08 & 0.21 & $-0.34 *$ & -0.17 & 0.17 & $-9.97 *$ \\
\hline 18816 & 0.00 & -0.41 & $0.33 *$ & -1.02 & $0.77 * *$ & $-12.3 * *$ \\
\hline M 2 & -0.08 & 0.07 & $0.28 *$ & -0.17 & $-0.43^{*}$ & $11.63 *$ \\
\hline MAI 175 & $0.30 *$ & -0.12 & -0.15 & -0.33 & $0.51 * *$ & 1.70 \\
\hline MAI 386 & $-0.27 *$ & $1.16^{* * *}$ & 0.04 & $2.33 * *$ & $0.44 *$ & $11.85^{*}$ \\
\hline MAI 387 & 0.12 & -0.43 & $-0.29 *$ & $-1.96 * *$ & -0.31 & $-14.79 * *$ \\
\hline MQPM 43 & 0.04 & $0.92 * *$ & $0.39 * *$ & 0.74 & -0.01 & $12.61 * *$ \\
\hline 747 & -0.07 & 0.10 & $0.31 *$ & $1.65^{*}$ & $0.38 *$ & 2.56 \\
\hline 757 & $0.28 *$ & 0.14 & -0.04 & 0.84 & -0.11 & 4.32 \\
\hline 18701 & 0.09 & $1.43 * *$ & 0.09 & 1.02 & -0.18 & -4.04 \\
\hline Gi-Gj@5\% & $0.434^{* * *}$ & $1.062 * *$ & $0.42 * *$ & $1.976^{* * *}$ & $0.531^{* *} *$ & $14.628 * *$ \\
\hline Gi-Gj@1\% & $0.6^{* *}$ & $1.468 * *$ & $0.581 * *$ & $2.732 * *$ & $0.734 * *$ & $20.223^{* *}$ \\
\hline
\end{tabular}

* Significance at $\mathrm{P}=0.05 ; * *$ Significance at $\mathrm{P}=0.01$ 
3.3 Relationship of gca effects of inbred lines with their per se performance

Significant positive but low magnitude of correlation between per se performance of the inbreds and their gca effects for ASI, ear length, ear width, kernels rows ${ }^{-1}$, Kernel rows ear ${ }^{-1}$

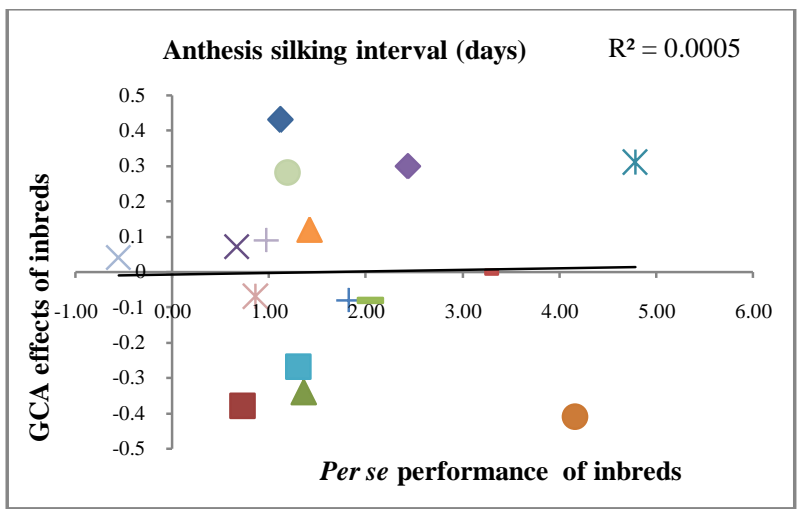

Figure 1 Correlation between per se performance and gca effects of inbreds for anthesis silking interval (days)

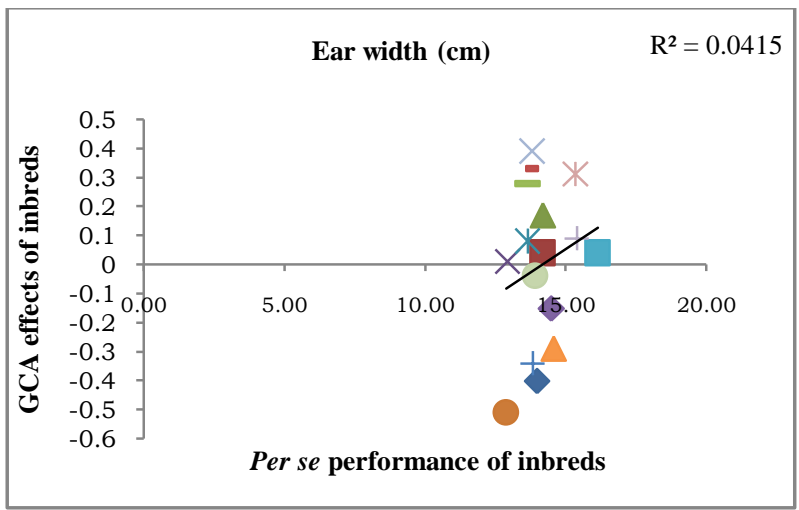

Figure 3 Correlation between per se performance and gca effects of inbreds for ear width $(\mathrm{cm})$

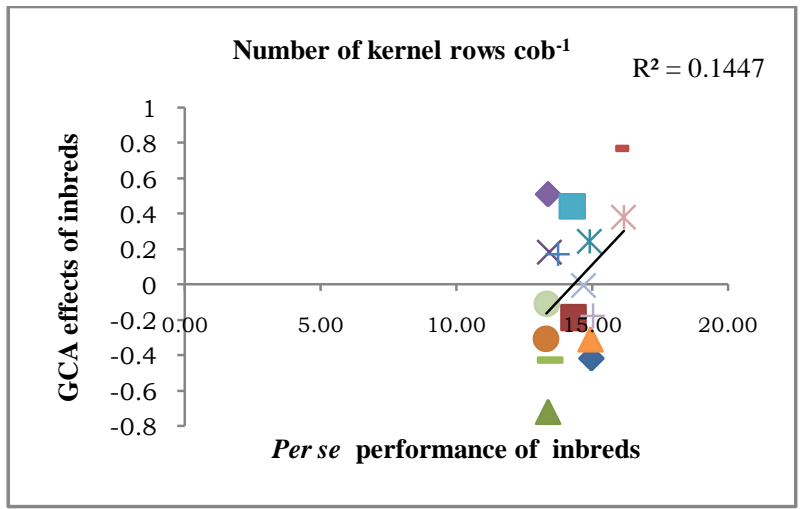

Figure 5 Correlation between per se performance and gca effects of inbreds for kernel rows $\mathrm{cob}^{-1}$
(Figure 1-6), suggested that per se performance of the lines is not a good indicator of their $\mathrm{gca}$ effects for any of the traits. The poor correlation between per se performance and gca effects of inbred line could be attributable to different sets of genes controlling per se performance and gca effects for target traits (Turner, 1953;

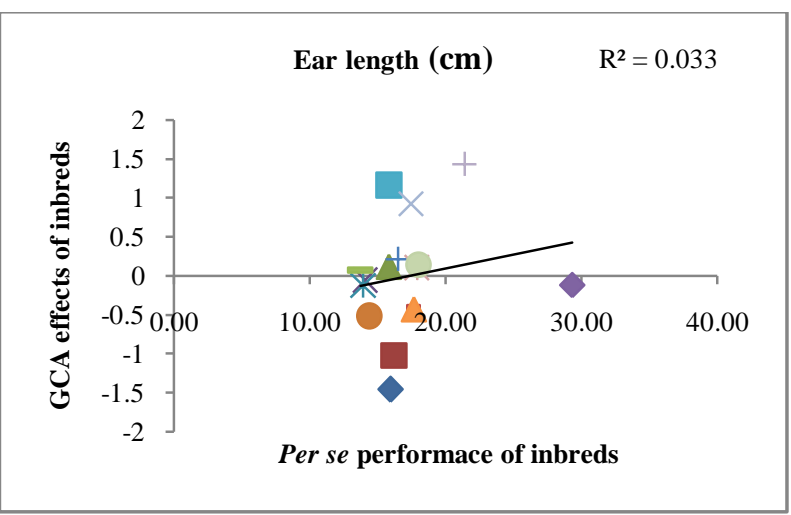

Figure 2 Correlation between per se performance and gca effects of inbreds for ear length $(\mathrm{cm})$

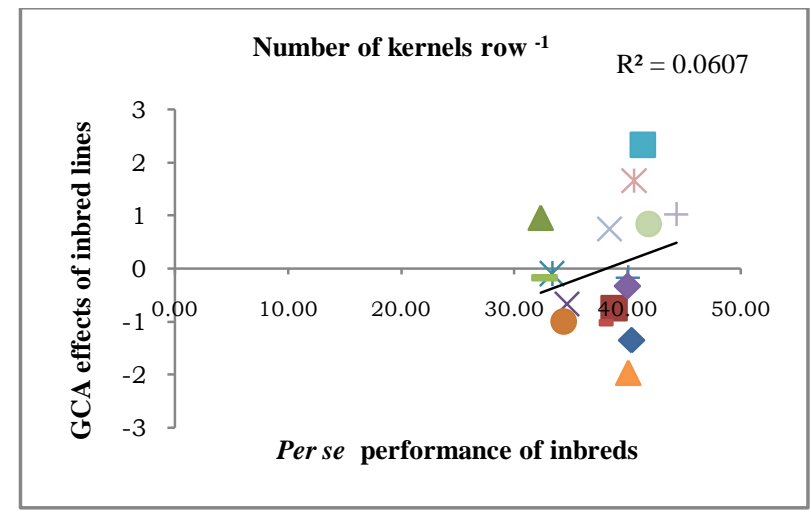

Figure 4 Correlation between per se performance and gca effects of inbreds for kernels row ${ }^{-1}$

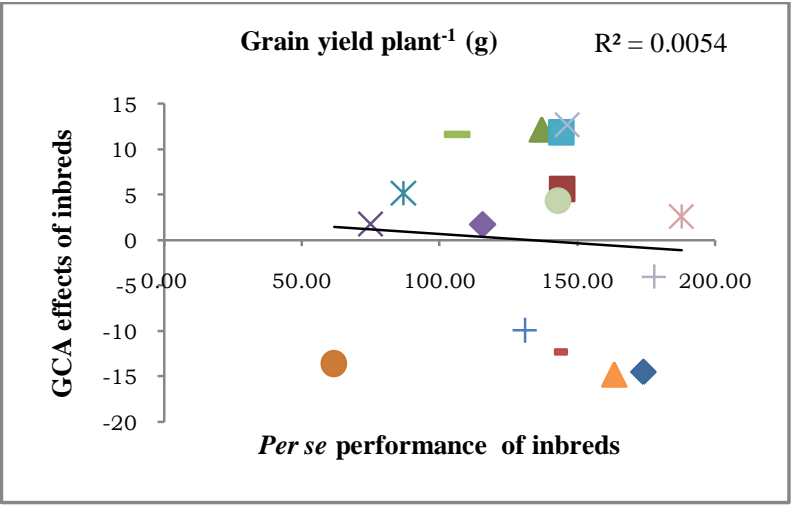

Figure 6 Correlation between per se performance and gca effects of inbreds for grain yield plant ${ }^{-1}(\mathrm{~g})$

Journal of Experimental Biology and Agricultural Sciences http://www.jebas.org 
Ai-Zhi \& Zhang, 2012). Significance of mean squares attributable to gca and sca (Table 1) provide evidence for the involvement of both additive genetic variance and dominance genetic variance for the expression of grain yield plant ${ }^{-1}$ and its attributing traits.

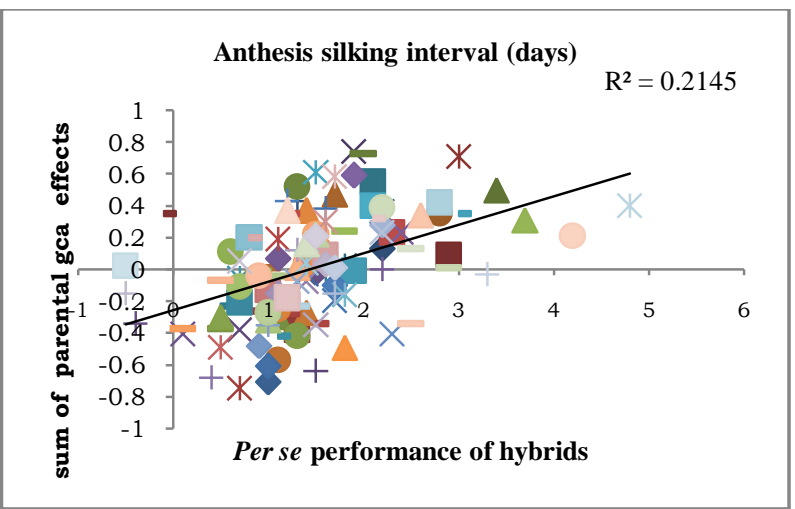

Figure 7 Correlation between per se performance of hybrids and sum of parental gca effects for anthesissilking interval (days)

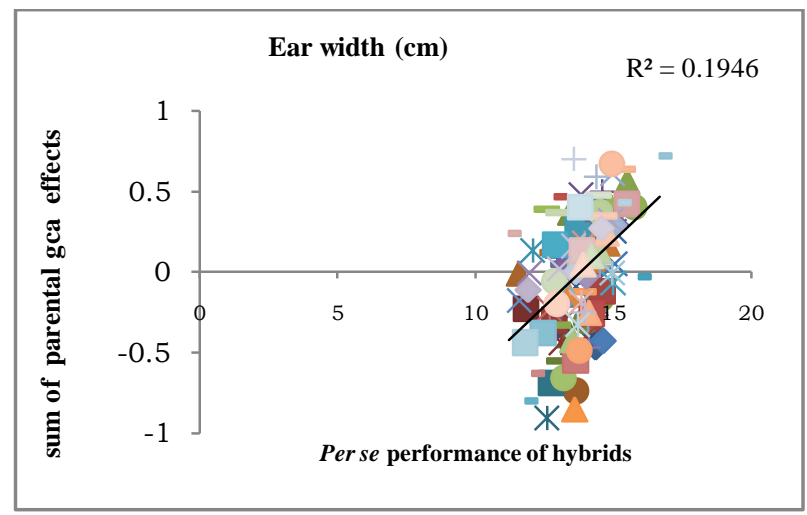

Figure 9 Correlation between per se performance of hybrids and sum of parental gca effects for ear width $(\mathrm{cm})$

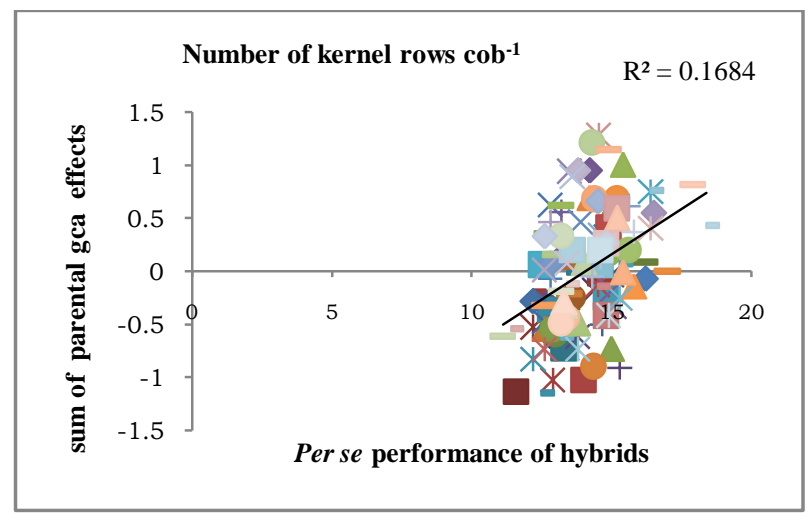

Figure 11 Correlation between per se performance of hybrids and sum of parental gca effects for kernel rows $\mathrm{cob}^{-1}$
3.4 Relationship of hybrid per se performance with sum of parental gca effects

Relatively high magnitude of correlation between sum of the parental gca effects with hybrid per se performance for all the traits (Figure 7-12), suggested that parental gca effects retained

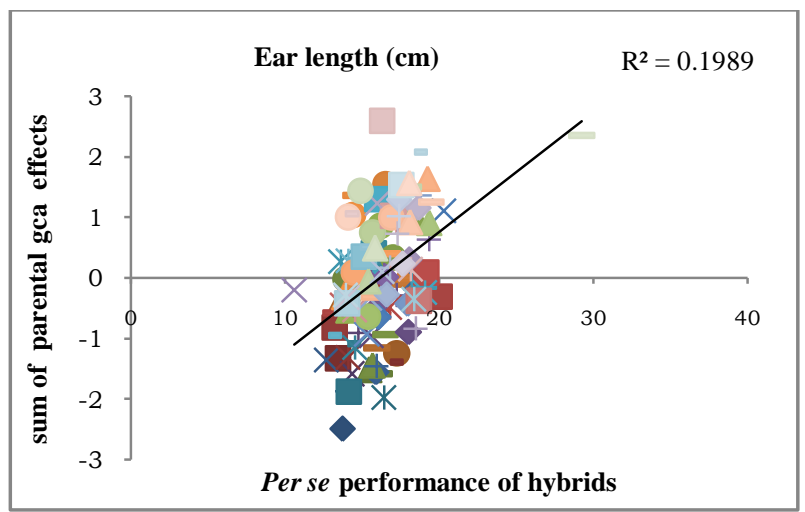

Figure 8 Correlation between per se performance of hybrids and sum of parental gca effects for ear length $(\mathrm{cm})$

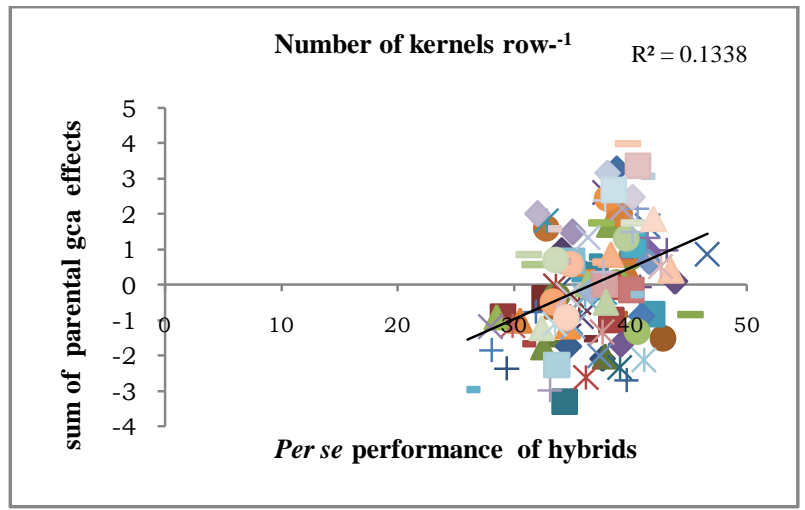

Figure 10 Correlation between per se performance of hybrids and sum of parental gca effects for kernels row ${ }^{-1}$

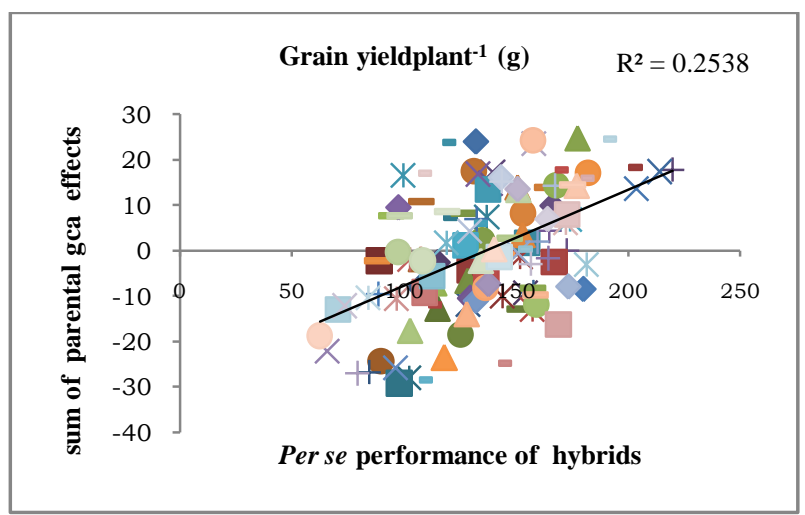

Figure 12 Correlation between per se performance of hybrids and sum of parental gca effects for grain yield palnt ${ }^{-1}(\mathrm{~g})$

Journal of Experimental Biology and Agricultural Sciences http://www.jebas.org 
fairly higher predictability of hybrid per se performance. It helps to predict hybrids performance based on their parental gca which is attributable to additive effect genes (Falconer \& Mackay, 1996). Prediction of hybrid heterosis based on parental gca effects would save substantial resources as it enables the evaluation of only a few hybrids that are predicted to be most promising ones. The utility of parental gca effects for predicting hybrid per se performance has also been reported by Schrag et al. (2009) and Sowmya \& Gangappa (2018).

\section{Conclusion}

From this study it is evident that the correlation between per se performance of hybrids and sum of parental gca effects will help in predicting the hybrids per se performance based on their parental gca effects for all the traits investigated, Hence, gca of parents can be used as a predictive tool for developing hybrids with superior per se, which in turn helps in reducing the use of input resources and enhances the breeding efficiency.

\section{Acknowledgement}

The senior author thankfully acknowledges the financial support from University Grant Commission (UGC) in the form of Rajiv Gandhi National Fellowship (RGNF) for pursuing Ph.D. programme.

\section{Conflict of Interest: Nil}

\section{References}

Ali F, Muneer M, Rahman H, Noor M, Durrishahwar, Shaukat S, Yan JB (2011) Heritability estimates for yield and related traits based on testcross progeny performance of resistant maize inbred lines. Journal of Food, Agriculture and Environment 9:438-443.

Al-Zhi LV, Zheng Y (2012) Conversion of the statistical combining ability into a genetic concept. Journal of Integrative Agriculture 11: 43-52.

Bernardo R (2010) Breeding for Quantitative traits in Plants. Second Edition, Stemma press, Woodbury, Minnesota.
El-Hosary AAA (2014) Relative values of three different testers in evaluating combining ability of new maize inbred lines. International Journal of Genetics 8: 57-65.

Falconer DS, Mackay TFC (1996) Introduction to Quantitative Genetics. Addison Wesley Longman Limited, London.

Fasahat P, Rajabi A, Rad JM, Derera J (2016) Principles and utilization of combining ability in plant breeding. Biometrics \& Biostatistics International Journal 4: 1-24.

Griffing O (1956) Concept of general and specific combining ability in relation to diallel crossing system. Australian Journal of Biological Sciences 9:463-493.

Hayman BI (1954) The Theory and analysis of diallel crosses. Genetics 39:789-809.

Hosana GC, Alamerew S, Tadesse B, Menamo T (2016). Test Cross Performance and Combining Ability of Maize (Zea Mays L.) Inbred Lines at Bako, Western Ethiopia. Global Journal of Science Frontier Research: D Agriculture and Veterinary 15:1-24.

Kanagarasu S, Nallathambi G, Ganesan KN (2010) Combining ability analysis for yield and its component traits in maize (Zea mays L.). Electronic Journal of Plant Breeding 1: 915-920.

Schrag TA, Frisch M, Dhillon BS, Melchinger AE (2009) Marker based prediction of hybrid performance in maize single crosses involving doubled haploids. Maydica 54: 353-362.

Sowmya HH, Gangappa E (2018) Testing early generation $\left(\mathrm{F}_{4}\right)$ maize inbred lines for general combining ability. Mysore Journal of Agricultural Sciences 52: 560-565.

Sprague GF, Tatum LA (1942) General vs. specific combining ability in single crosses of Corn. Agronomy Journal 34: 923-932.

Turner JK (1953) A study of heterosis in upland cotton and combining ability and inbreeding effects. Agronomy Journal 45 : 487-490. 